\title{
Terrorism: The Banality of a Global Evil
}

\author{
Brij Mohan*
}

Louisiana State University, Baton Rouge, LA 70803, USA

\begin{abstract}
The ubiquity of contemporary terrorism defines the evilness of banality. A typical terrorist profile does not exist; it's atypical character of this vile phenomenon that chills human rationality. This article briefly unravels the dynamics of terror and its implications. Un-separated terrorism and counter-terrorism destroy the climate for civil transformation. Our counterproductive interventions retard progress and breed neo-imperial atavism. This is modernity's self-created Catch 22. Banality of terror calls for a paradigmatic analysis of institutional behaviors and their transformations.
\end{abstract}

"On the level of historical insight and political thought there prevails an ill-defined, general agreement that the essential structure of all civilizations is at the breaking point. ...Desperate hope and desperate fear often seem closer to the center of such events than balanced judgment and measured insight. The central events of our time are not less effectively forgotten by those committed to a belief in an unavoidable doom, than by those who have given themselves up to reckless optimism."

Hanna Arendt [1]

"Phillip Garrido did printing work for a Pittsburg recycling center for more than a decade, and he did it well. Some of the receipts and envelopes came with lovely children's designs, said Maria Christenson, owner of Christenson Recycling Center. His daughter did them, Garrido proudly told her... Then, on Wednesday, Garrido brought his wife, the girls and Dugard - who went by "Allissa" — into a Concord parole office, where questions from police revealed Dugard's identity and led to the couple's arrest. The next day, in an interview from jail, he told a Sacramento TV station, "If you take this step at a time, you're going to fall over backwards, and in the end, you're going to find the most powerful, heartwarming story."

A typical terrorist profile does not exist; it's atypical character of this vile that chills human rationality. Phillip Garrido's unspeakable private life is a monstrous reality. He kept his victim, according to a detective, in a "storage unit where the rape occurred as a 'sex palace', with a bed, rug on the floor and walls, various sex aids, sexual magazines and videos, stage lights and wine" telling "that he preferred sex by force" [2].

*Address correspondence to this author at the Louisiana State University, Baton Rouge, LA 70803, USA; E-mail: dialog@cox.net

\#This article is largely based on my keynote address delivered (in absentia) to the UGC sponsored International Seminar on Society and Tourism, T.M. Bhagalpur, India, May 20-21.

${ }^{1}$ http://www.contracostatimes.com/ci_13231389? source=most_viewed August 30, 2009)
From Garrido's "sex palace" to the grisly horrors of a genocidal carnage, we are left with victims, their nightmares and unfolding tales of torture and abominable conduct. The ultimate casualties are human dignity, respect and acceptance that constitute the foundation of any civil society.

Modern terrorism is a wolf child of man's psychopathologically inexplicable drive to isolate, exploit, control and destroy the very people whom he loves and hates at the same time. Garrido's sex slaves and Hitler's Jews could be understood as victims of the same necrophilous trappings that have played havoc with humanity ${ }^{2}$. Jews were certainly major targets, but the handicapped, gypsies, gays, Catholics, communists and a number of others were also victims.

Hannah Arendt argued for political equality to insure that Jews did not remain exposed and vulnerable to "the fate that awaits all who stand on periphery of citizenship: ill treatment, and the personal compromises and guilt that attend integration on unequal terms" [3].

Acquiring "the courage necessary to go forward together to build a future open to hope" 3 poses the greatest challenge that humankind faces in the 21 st century. "At a time of world food shortage, of financial turmoil, of old and new forms of poverty, of disturbing climate change, of violence and deprivation which force many to leave their homelands in search of existence, of the ever present threat of terrorism, of growing fears over the future, it is urgent to rediscover grounds for hope," the Pope concluded [4].

Papal homily is encouraging in a world bedeviled by violence and counter-violence. It's incumbents on citizens of the world to face this challenge upfront before it's too late. The banality of terror is an unfortunate aspect of human conditions that suffocate existential necessities to every human being. It is imperative that we understand the dynamics before we attempt any remedial or preventive intervention.

I will briefly touch upon the nature and implications of unbridled violence and counter-violence that has destroyed

\footnotetext{
${ }^{2}$ See Chs 12 and 13 in Erich Fromm [17].

${ }^{3}$ Pope Benedict XVI gave this message of hope when he delivered his "Urbi et Orbi" (The Advocate, Associated Press, April 13, 2009: 2A.
} 
the civil character of our contemporary society. This, hopefully, might led to strategies of hope. Terrorism and counterterrorism cannot be separated. Noam Chomsky has a point when he asserts that Britain and US are the most powerful terrorist states in the world ${ }^{4}$.

Terrorism defies a specific definition ${ }^{5}$. You know it when you see it ${ }^{6}$. Deadly despair is the womb of terrorism; it corrupts rationality and breeds hate and violence. To characterize this as a new perversion of ideology and/or faith would be a mistake. History, replete with genocidal repressions and countless mayhem, is inked in innocent human blood. The rise and fall of colonial empires is, however, closely related to the modern evil of terror across nations.

Also, it would be erroneous to see terror only as a macroissue. We Indians practice 'racism' -yes, racism-and sexism even in our own families. When Jyotsna $a^{7}$ threatens to kill herself unless her parents give a stupendous dowry to her boy friend's rapacious family, we are really confronting, accepting and condoning domestic terrorism which manifests itself in wife burning and dowry deaths. My own baby sister, married about 52 years, fought against the brutality of a lifelong tragedy succumbed to domestic terror eight years ago (May 17, 2001) ${ }^{8,9}$. To deny this reality is refused to accept the existence of reason. You multiply such episodes in a vastly complex politico-religious field filled with venomous fumes; you have a perfect storm of terror. Sure, "we know enough at this moment to say that the God of Abraham is not only unworthy of the immensity of creation; he is unworthy even of man" [5].

We live in a dysfunctional civilization. Al Gore's The Assault on Reason shows how "the politics of fear, secrecy, cronyism, and blind faith has combined with degradation of the public sphere to create an environment dangerously hostile to reason" [6]. He writes: "At the time George W. Bush ordered American forces to invade Iraq, 70 percent of Americans believed Saddam Hussein was linked to 9/11. Voters in Ohio, when asked by pollsters to list what stuck in their minds about the 2004 presidential campaign, most frequently named Bush ads that played to fears of terrorism" [6].

\footnotetext{
${ }^{4}$ http://www.youtube.com/watch?v=_6TgL8ruF4M\&NR=1 (Retrieved September 15, 2009)

${ }^{5}$ However, I find these two definitions useful for a general discussion. “ Terrorism is an interdisciplinary topic that requires the contributions of experts in the areas of history, political science, social science, philosophy, religion, psychology, sociology, finance, strategic studies, international relations, criminal justice, crime prevention and control, public safely, warfare, counter terrorism theory and practice, anthropology, languages, and cultural studies" [19].

"....terrorism may can be defined as the deliberate generation, instillation, and exploitation of fear into a competing group, party and government, or public opinion through violence or the threat of violence with the goal of introducing political change" $[18,19]$. Cf. Bryant and Peck [19].

6"'The Web site of the United Nations High Commissioner for Human Rights contains a four-page document listing various definitions of the term "torture." Most center on two points: that torture is any act that intentionally inflicts "severe pain or suffering, whether physical or mental," in the words of a 1975 U.N. declaration, to serve a state purpose like gathering information or intimidating dissenters; and that pain or suffering that arises from lawful punishment does not count" (Times Topics, retrieved May 17, 2009),

http://topics.nytimes.com/top/reference/timestopics/subjects/t/torture/index.html?scp=1 -spot\&sq=\&st=nyt

${ }^{7}$ A pseudonym

${ }^{8}$ See my book The Practice of Hope dedicated in memoriam [16].

${ }^{9}$ This paper is dedicated to Shakuntala Sharma who passed away May 17, 2001 as a victim of lifelong domestic terror.
}

In India such fears are hideously employed to orchestrate pogroms in a hyper democracy. The most obscene and pernicious example of such a terror is a masterfully designed mayhem in Godhara after the destruction of the Babri mosque in Ayodhya. India's New Face ${ }^{10}$ is painted with the fecklessness of its colorless communal divide. Robert D. Kaplan succinctly writes in The Atlantic:

"As much as India fears Pakistan, it fears Pakistan's collapse even more. The threat of Islamic anarchy in the region is perfectly suited to the further consolidation of Hindu nationalism" [7].

Fundamentalism, whether Muslim or Hindu or Christian, is an antithetical to civility and peaceful coexistence. The evil is deeply rooted in history's crimes against innocent people which are played out in different acts as part of the same unfolding drama. Kaplan's reference to Ghazni is worth a note: "During a trip to India last fall, whenever I mentioned the events of 2002 to Hindu nationalists, they would lecture me about the crimes of Mahmud of Ghazni. For these Hindus, the past is alive, as if it happened yesterday...I also couldn't help but think of what Hanif Lakdwala had asked me, in a plea as much as a question: 'What can we poor Muslims of today do about Mahmud of Ghazni?" [7].

Jihad and its internationalization are attributable to AlQaeda [8]. Even though much of its menace was not globally felt until "the road to 9/11" looked clearer, its genesis, historically and physically, lies elsewhere. No problem, let alone the one that threats our civil society, can be unraveled unless we know its root causes.

Perhaps Genesis must be rewritten. The Garden of Eden was ruined by a snake. The age of innocence, as Rousseau would have us believe, ended the day when some idiot plotted a piece of land off claiming it as his own. The rise of private property, foundation of the civil society in other words, destroyed the romance of primitive innocence. The trajectory of this acquisitive instinct may be linked to the rise and fall of both socialism and capitalism. This also helps to understand why new forms of authoritarians crop up almost everywhere. The state as an institution has been threatened by the Irish Red Brigade ${ }^{11}$, Tamil Tigers, Taliban, and lately Somali pirates. It's difficult to dismiss them as ordinary local and or regional revolts. Pirates and hijackers are not distant cousins of those who often kill innocent people for achieving their political ends. To understand the dynamics of this social devolution is to find a plausible solution to the current crisis. Rogue states are failed orders of established rule; their meltdown manifests itself in terror whenever it pays off.

The oppressive states with inbuilt structure of exclusion, punishment and torture have served as engines of anti-state terror. It may be argued that terrorism is a violent revolt of militants against the apparatus of control itself. Modern code of punishment replaced torture by a new morality and economy of punishment. Michel Foucault brilliantly presents

\footnotetext{
${ }^{10}$ See Robert D. Kaplan [7].

11"By global standards, 20th Century Britain has been remarkably free from political violence. Red Action hopes to change all that. Angry, ruthless and close to the IRA, they preach socialism through terror." http://libcom.org/library/red-action-ira-londonbombs-independent (retrieved May 17, 2009).
} 
this approach: "From being an art of unbearable sensations punishment has become an economy of suspended rights" [9].

"But the punishment-body relation is not the same as it was in the torture during public executions.... The modern rituals of execution attest to this double process: the disappearance of the spectacle and the elimination of the pain" [9].

It's interesting to note that torture of Iraqi prisoners in Iraq and Guantanamo Bay on the one hand and Taliban's return to barbaric practices of punishment is conceptually not unrelated. Continued employment of torture and its counterproductivity compounded by marginalization, exclusions and hopelessness tranquilized by the false logic of faith and martyrdom helps ventilate the repressed fantasies of coercive and totalistic systems.

Let's revisit the archeology of some colonial oppression, its devastating legacy and counterproductive consequences. Narendra Singh Sarila, one of Mountbatten's ADCs, has documented how British rule ended with India's partition. Today Pakistan is characterized as the "most dangerous place on earth". Pakistan is an abortion of South Asia's unity which posed threats to colonial interests [10]. A sort of wolf child was conceived and delivered on August 15, 1947 at the time of India's Partition, which is euphemistically called independence day. Sarlia has produced a mountain of documents which unravel the "untold story of India's partition" under The Shadows of the Great Game. He concludes:

"Many of the roots of Islamic terrorism sweeping the world today lie buried in the partition of India" [10].

History and counter-history present two different stories. Martyrs and terrorists also depict the same irony. Sardar Bhagat Singh and his friends were executed for a benign explosion that marked a protest against the British rule. They were 'terrorists' too. But are they? The point is not to justify any act of terror howsoever understandable it is. It's the malignancy of power and its brutality that is obscene and dreadful, therefore, unacceptable. What we saw at the Taj Hotel at about 9 p.m. on November 26 to 28, 2008 in Mumbai epitomizes that evil ${ }^{12}$. An act of evil is always counterproductive. Pakistan has become a victim of its own demons. Its infamous spy agency (ISI) in alliance with the CIA created a monster to fight against the Russian occupation. When the Russians left, they were deviously employed in Kashmir. Now the Taliban has become Pakistan's Frankenstein.

Terror and Consent according to Phillip Bobbitt represents "The wars for the twenty first century" [11]. "Almost every wildly held idea we currently entertain about twenty-first century terrorism and its relationship to the wars and against terror is wrong and must be thoroughly rethought," is boldly printed on the cover. His conclusion is worth a note:

\begin{abstract}
"Waging wars against terror is a historic struggle to preclude a world in which terror rather than consent establishes the State's legitimacy. What is at stake in the wars against terror is nothing less than building a basis of legitimacy for the new, emerging constitutional order" [11].
\end{abstract}

"The State is the organized authority, domination, and power of the possessing classes over the masse...the most flagrant, the most cynical, and the most complete negation of humanity... There is no horror, no cruelty, sacrilege, or perjury, no imposture, no infamous transaction, no cynical robbery, no bold plunder or shabby betrayal that has not been or is not daily being perpetrated by the representatives of the state, under no other pretext than elastic words, so convenient and yet so terrible: "for reasons of state." This is an epigraph written by Michael Bakunin in a book by Noam Chomsky [12].

The legitimacy of the nation state is in question and no superpower is immune to this staggering contradiction. It's the state that legitimizes coercion and institutional brutality. How can it be illegitimate? I wonder how Habermas would explain this crisis in English! As I see: This dedevelopmental paradox is counter-evolutionary. It retards progress and breeds atavism. The cultural anomalies and conflicts have placed individual, society and state in the ultimate Catch 22. This requires a paradigmatic analysis of institutional behaviors which unravel the banality of terror:

1) Breakdown of social contract

2) Illegitimacy of states of terror

3) Contrapuntal social development

These diagnostic elements constitute a step toward understanding the problem that warrants dispassionate analysis. I have dealt with some of these issues elsewhere as planks of a mega-plan toward global transformation [13, 14] It's imperative that the $20^{\text {th }}$ century approaches to global security are rethought through and replaced by a new "postmaterial consciousness" and reflective action if human survival, peace and coexistence are our goal. I conclude this paper by quoting a self-analytical reflection from Susan Faludi's The Terror Dream:

"When an attack on home soil causes cultural paroxysms that have nothing to do with the attack, when we respond to real threats to our nation by distracting yourselves with imagined threats to femininity and family life, when we invest our leaders with a cartoon masculinity and require of them bluster in lieu of capacity for rational calculation.... when we base our security on a mythical male strength that can only measure itself against a mythical female weaknesswe should know that we are exhibiting the symptoms of a lethal, albeit curable, cultural affliction.... That self-delusion, so deeply ingrained in our history, so heavily defended by our culture, calls out for refutation" [15].

\footnotetext{
${ }^{12}$ See Frontline, December 19, 2008, Reign of Terror (Cover)
} 
The pain and suffering of "Hazar Chaurasee Ki Ma"13 should not go in vain if people of the world unite against the culture of terror that breeds death and destruction. Hermeneutics of transformation implies discursive practice of hope against: alienation, arrogance, intolerance and oppression which lead to "ethnic cleansing, terrorism, and subjugation in a host of nefarious forms and structures" [16].

"Isolation may the beginning of terror; it certainly is its most fertile ground; it always is its result" [1].

\section{REFERENCES}

[1] Arendt H. The origins of totalitarianism. New York: A Harvest Book 1975; 7: 474.

[2] Cohen S, Donald B. Questions remain in missing girl case. The Advocate, August 30, 2009; 8A.

\footnotetext{
${ }^{13}$ A film based on Hajar Churashir Ma (the mother of 1084), " a major literary masterpiece by a veteran Bengali literary figure and brave social activist, Mahasweta Devi. This widely read and translated novel displays Devi's in-depth social awareness and an unsurpassed literary maturity which enabled her to experiment aptly and freely with the condensed plot and the narrative technique. Written during 1973-1974, the novel attempts to probe into the Naxalite movement of the early 1970's from a feminist and humanist point of view. The novel aptly mirrors a mother's attempt to interpret her youngest son's association with the Naxalite movement, a rebellion which found its roots in a small village of Naxalbari, North Bengal. The limited fire of violent rebellion spread rapidly in and around its place of origin, bringing the peasants and the intellectuals together and engulfing too many young lives and dauntless hearts" (http://www.shvoong.com/books/novel/1644528-hajar-churashir-ma/ retrieved May 17, 2009).

(c) B.Mohan 2009

dialog@cox.net
}

Baehr P, Ed. The portable Hanna Arendt. London: Penguin Books 2000; p. 11.

[4] Winefield NP says world needs hope. The Advocate, April 13, 2009; p. 2A.

[5] Harris S. The end of faith: religion, terror, and the future of reason. New York: W.W. Norton 2004; p. 226.

[6] Gore Al. The assault on reason. New York: Penguin 2007.

[7] Kaplan RD. India's new face. The Atlantic, April 2009; p. 74-81.

[8] Wright L. The looming tower: Al-Qaeda and the road to 9/11. New York: Vintage Books 2006; p. 375.

[9] Foucault M. Discipline \& punish. New York: The Vintage Books 1977; p. 11.

[10] Sarila NS. The shadows of the great game: The untold story of India's partition. New York: Carroll and Graf Publications 2006; 11: (emphasis added).

[11] Bobbitt P. Terror and consent. London: Penguin 2008; p. 12.

[12] Chomsky N. For reasons of state. New York: The New Press 2003.

[13] Mohan B. Global development: post material values and social praxis. New York: Praeger 1992.

[14] Mohan B. Fallacies of development: Crises of human and social development. New Delhi: The Atlantic Press 2007.

[15] Faludi S. The terror dream: fear and fantasy in post-9/11 America 2007; p. 295.

[16] Mohan B. The practice of hope: Diversity, discontent and discourse. Philadelphia, PA: Xlibris (Random House) 2002; p. 16.

[17] Fromm E. The anatomy of human destructiveness. New York: Fawcett Crest 1975; 362-410: 411- 74 .

[18] Noble K. Tabernacle of hate: why they bombed Oklahoma City. Prescott, Ontario: Voyager 1998.

[19] Viano EC. Terrorism. In: Bryant CD, Dennis LP, Eds. $21^{\text {st }}$ Century sociology: A reference handbook. Thousand Oaks, CA: Sage Publications 2007; vol. 2: pp. 313-20.

Received: May 27, 2009

This is an open access article licensed under the terms of the Creative Commons Attribution Non-Commercial License (http: //creativecommons.org/licenses/by$\mathrm{nc} / 3.0 /$ ), which permits unrestricted, non-commercial use, distribution and reproduction in any medium, provided the work is properly cited. 